Acta vet. scand. $1969,10,219-224$.

From the Department of Pharmacology and the Department of Anatomy, Veterinary College of Norway, Oslo.

\title{
THE ULTRASTRUCTURE OF FREE INTESTINAL CELLS ISOLATED WITH EDTA
}

By

E. Dybing, P. H. J. Nafstad and E. Sфgnen

The preparation of single epithelial cells is a logical extension of in vitro studies (Wilson 1962). The first method for removal of intestinal mucosal cells was digestion with trypsin (Harrer et al. 1964, Stern \& Reilly 1965). According to unpublished observations, these cells seemed to be morphologically intact under the electron microscope.

During the investigation on the effect of calcium-binding substances on intestinal absorption, a fragmentation of the intestinal epithelium caused by the calcium chelator EDTA was noted (Søgnen 1965, 1967).

Glucose metabolism in these cells was almost identical compared to the normal intestinal utilization (Søgnen 1965), which suggested that the EDTA-preparation might yield only moderately biochemically and morphologically altered cells.

The scope of this investigation was to study the structure of these cells and to compare them with the normal intestinal cell.

\section{MATERIALS AND METHODS}

According to the method described by Søgnen (1967), everted loops of the rat small intestine (Wilson \& Wiseman 1954) were filled with $20 \mathrm{ml} \mathrm{Ca}{ }^{++} / \mathrm{Mg}^{++}$-free $\mathrm{Krebs}$ Ringer phosphate solution containing $2 \mathrm{mM}$ EDTA and incubated at $0^{\circ} \mathrm{C}$ for $1 \mathrm{hr}$. Thereafter the epithelium was detached by manual shaking; the outer fluid, now a suspension of cells, was spun down. After double washing with ice-cold physiological saline containing twice the 
iso-ionic amount of $\mathrm{Ca}^{++}$and $\mathrm{Mg}^{++}$(to restore equilibrium), the cells were resuspended in a Krebs Ringer phosphate glucose solution, where they would be metabolically active for at least $1 \mathrm{hr}$. A pellet for microscopic examination was obtained after spinning down with $3 \%$ glutaraldehyde.

The reference material was taken from the intestine of perfused rats ( $3 \%$ glutaraldehyde in Millonigs phosphate buffer (with glucose) and $3 \%$ Macrodex, pH 7.3). Further fixation was done with a $2 \%$ solution of osmium tetroxide in Millonigs phosphate buffer for $2 \mathrm{hrs}$. After dehydration in acetone series, infiltration and embedding in araldite followed. Sections were stained with aquous uranyl acetate and lead citrate. Finally, the sections were examined under the electron microscope (Siemens Elmiscope Ia).

\section{The normal cell}

\section{OBSERVATIONS}

It is well-known that normal intestinal epithelial cells of the rat (Fig. 1) are of the tall columnar type, with basically located oval nuclei containing denser nucleoplasm at their periphery (Trier \& Rubin 1965). Apically are located the characteristic microvilli. As has been pointed out, there is a difference in length

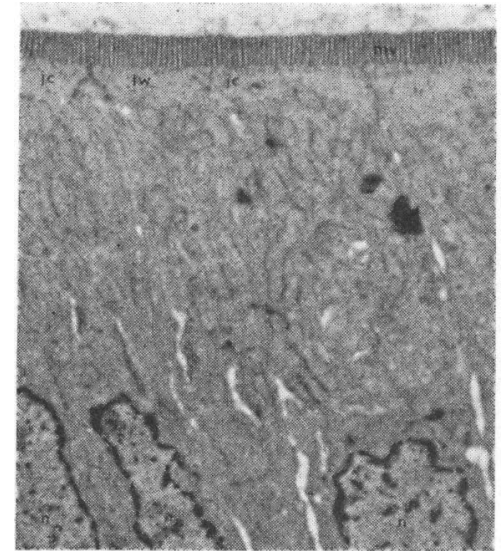

F i g u r e 1. Normal rat intestinal cells. The microvilli are here quite short. $n$ : nucleus; tw: terminal web; mv: microvilli; jc: junctional complexes. $\times 4.800$

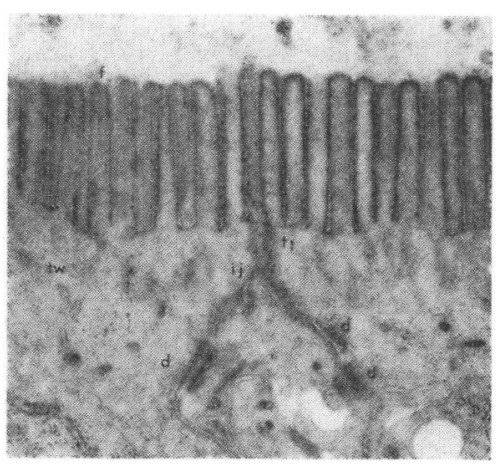

F i g u r e 2. Junctional $\mathrm{c}^{\prime}$,mplexes of the rat intestinal cell. Note the three-laminated structure of the microvillous membrane. $t j$ : tight junction; $\mathrm{ij}$ : intermediate junction; d: desmosomes; tw: terminal web; $f:$ fuzz. $\times \mathbf{1 8 . 0 0 0}$ 
and width of the microvilli depending on the location on the macrovilli. Most mitochondriae appear in the apical portion of the cells. A well developed endoplasmic reticulum is seen.

At a greater magnification (Fig. 2) the microvilli are seen as tightly spaced, finger-like processes clearly limited by a threelaminated membrane and covered by "fuzz". The central filamentous structures of the microvilli are seen to penetrate down into the terminal web.

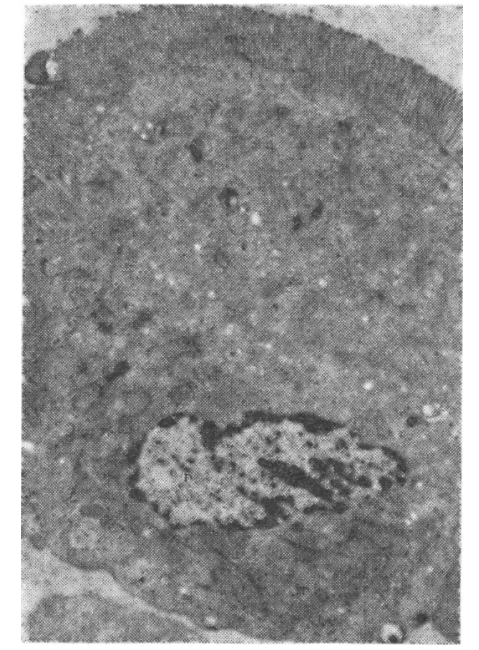

F i g u r e 3. A free intestinal epithelial cell with basically located nucleus surrounded by many mitochondriae. Note the microvillous filaments dipping into the terminal web. n: nucleus; mi: mitochondriae; mv: microvilli.

$$
\times 5.200
$$

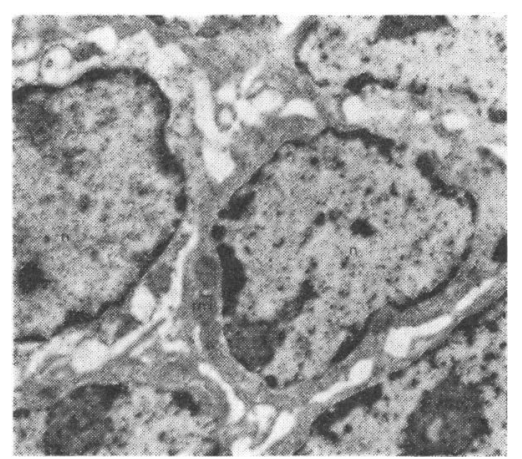

Figure 4. Free intestinal cells cut horizontally through their nuclei. The cells touch each other at cytoplasmatic protrusions. $\mathbf{n}$ : nucleus; mi: mitochondriae. $\times 5.400$

Desmosomes (Fawcett 1966), believed to be specialized junctional attachments of the cells, are visible in their different modifications (Fig. 2), i.e. tight and intermediate junctions, desmosomes. The lateral plasma membranes may show laminated foldings.

\section{The free cell}

The free intestinal cell (Figs. 3 and 4 ) has a more spherical appearance; a logical alteration for a structure with an elastic 

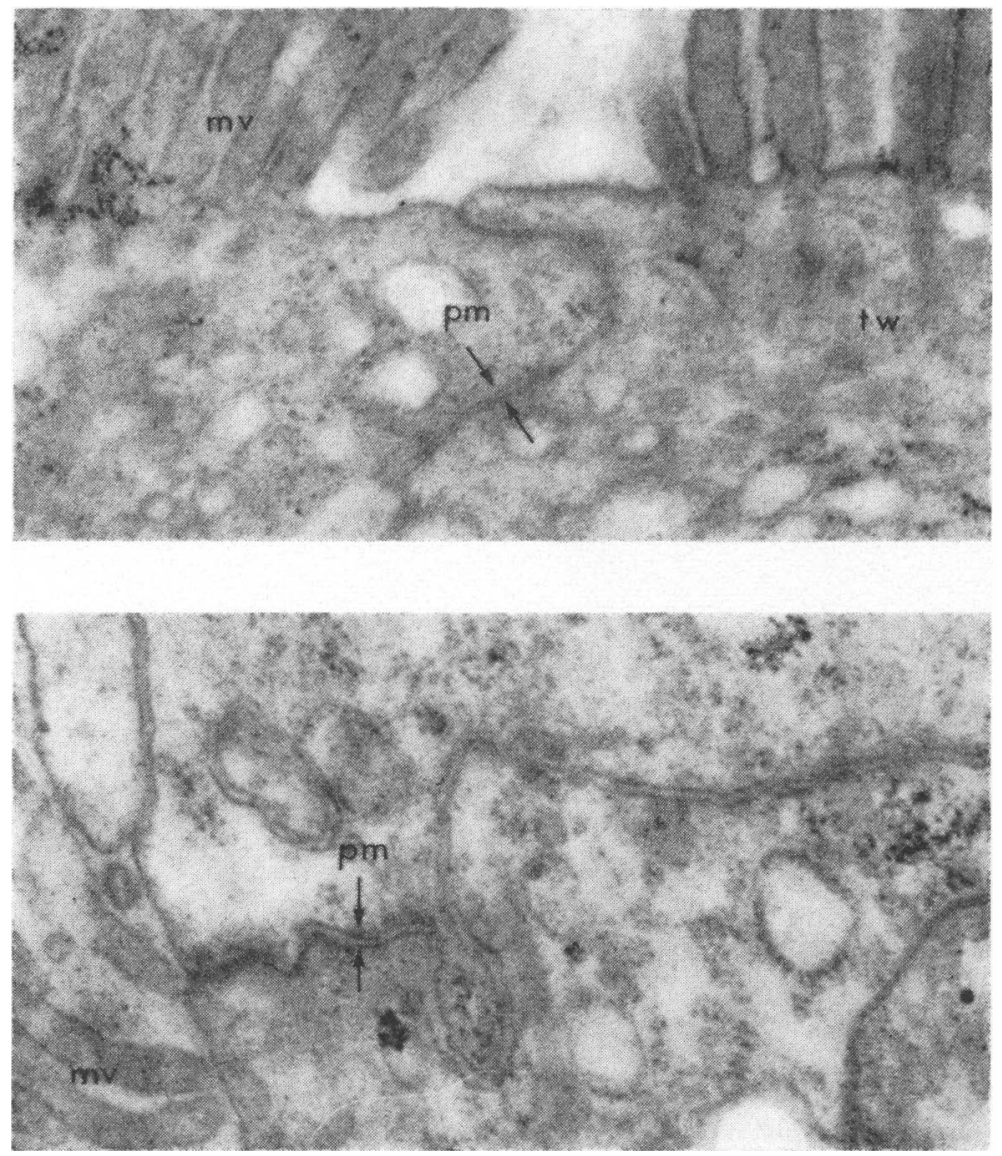

F i g u r e 5 a, b. Cell borders after EDTA-preparation. The junctional complexes have almost disappeared, the cells seem to stick together only by adhesional forces. mv: microvilli; tw: terminal web; pm: plasma membranes. $\times 46.400$

surface. Also the cell nuclei show a rounder form and are surrounded by more mitochondriae than usual; other prominent cytoplasmic changes are not visible. Owing to the modification of the cell outline, the microvilli become wider spaced, "fanned out". The structure of the plasma membranes seem to be morphologically intact, and they are clearly outlined.

The most apparent change is seen where cells lie adjacent to each other, not totally dispersed (Fig. 5a, b). The junctional complexes previously mentioned are mostly not seen or at least have greatly diminished in visibility. At a greater magnification 
the intermediate junctions and the desmosomes can hardly be seen, whereas the tight junctions mostly have kept their structural characteristics. The adjacent cell membranes near the free border of the cells have developed marginal foldings as if produced by adhesional forces.

Cell counts averaged $135-205 \times 10^{6}$ per ml packed cells. Mean nigrosin-negativity (Kaltenbach et al. 1958), expressing living cellular membranes, was $61-86 \%$. Differential counts showed mostly intestinal cells $(75-85 \%)$, but also naked nuclei $(10-15 \%)$ and leucocytes $(5-10 \%)$.

\section{DISCUSSION}

The described method for the isolation of free intestinal cells with the calcium chelator EDTA, yields cells that are only moderately changed morphologically. Although a quantitative estimation by the electron microscope is difficult, the impression was that most cells were intact. This was confirmed by the nigrosin-staining procedure and earlier biochemical results.

The fact that during the process of isolation, the junctional complexes of epithelial cells were modified or lost, leads to the question of the structural and functional importance of desmosomes and the role of calcium in such intercellular attachments. With the use of calcium chelators further information on this point might be gained.

\section{REFERENCES}

Fawcett, D. W.: The Cell. Its Organelles and Inclusions. W. B. Saunders, London 1966.

Harrer, D. S., B. K. Stern \& R. W. Reilly: Removal and dissociation of epithelial cells from the rodent gastrointestinal tract. Nature (Lond.) 1964, 203, 319-320.

Kaltenbach, J. P., M. H. Kaltenbach \& W. B. Lyons: Nigrosin as a dye for differentiating live and dead ascites cells. Exptl. Cell Res. $1958,5,112-117$.

Stern, B. K. \& R. W. Reilly: Some characteristics of the respiratory metabolism of suspensions of rat intestinal epithelial cells. Nature (Lond.) 1965, 205, 563-565.

Søgnen, E.: Intestinal transport of glucose and sulphanilamide in vitro at low calcium concentrations and in presence of calciumbinding substances. Acta pharmacol. (Kbh.) 1965, 22, 61-68. 
Søgnen, E.: A method for the preparation of suspensions of intestinal mucosal cells by means of calcium chelators. Acta vet. scand. $1967,8,76-82$.

Trier, J. S. \& C. E. Rubin: Electron microscopy of the small intestine: A review. Gastroenterology 1965, 49, 574-603.

Wilson, T. H.: Intestinal Absorption. W. B. Saunders, London 1962, p. 34.

Wilson, T. H. \& G. Wiseman: The use of sacs of everted small intestine for the study of the transference of substances from the mucosal to the serosal surface. J. Physiol. (Lond.) 1954, 123, 116-125.

\section{SUMMARY}

A brief electron microscopic study of free rat intestinal cells, isolated with the calcium chelator EDTA is given. The cells appeared morphologically intact, as was shown by nigrosin-staining. The junctional complexes were modified or lost.

\section{ZUSAMMENFASSUNG}

Die Ultrastruktur von freien Darmzellen isoliert mit Hilfe von EDTA.

Eine kurzgefasste elektronmikroskopische Untersuchung von freien Darmzellen von Ratten isoliert mit Hilfe von dem Kalziumbinder EDTA ist vorgenommen worden. Die Zellen schienen bei Nigrosinfärbung morphologisch intakt, jedoch waren die Verbindungszonen - die Desmosomen - meistens verschwunden.

\section{SAMMENDRAG}

Ultrastrukturen hos frie tarmceller isolert ved hjelp av EDTA.

Det er foretatt en kortfattet elektronmikroskopisk unders $\varnothing$ kelse av frie rottetarmceller isolert ved hjelp av kalciumbinderen EDTA. Cellene syntes morfologisk intakte ved nigrosinfarging, men forbindelseskompleksene - desmosomene - var for det meste borte. 